\title{
The little boy and his changing faces
}

\author{
After a false start in 2014, this year is shaping up to host a strong El Niño event. The question is why \\ were last year's predictions of the natural phenomenon wrong? And what is the state of knowledge on \\ the El Niño/Southern Oscillation (ENSO)?
}

All systems are go, with the much-anticipated El Niño event underway. The National Oceanic and Atmospheric Administration (NOAA) forecast a $>90 \%$ chance of the event continuing through the Northern Hemisphere winter and a strong chance $(\sim 80 \%)$ of continuing into the start of $2016^{1}$. The strength of the event is unknown and after the failure to forecast last year (discussed in a Commentary by McPhaden ${ }^{2}$ ), there may be some reluctance to make strong statements. That doesn't mean that all are shying away, a NASA climatologist is reported to have stated that a "Godzilla" event will happen ${ }^{3}$, with 1997/1998 being the last event worthy of this status.

Peru may be in for a tough time if this El Niño develops to a similar size, as the country experienced widespread flooding and deadly landslides in 1997/1998. In May of last year, Estudio Nacional del Fenómeno "El Niño" (ENFEN), the Peruvian national agency, declared an El Niño event, but other agencies did not. It all comes down to how you define an event - ENFEN base their definition on sea surface temperature (SST) anomalies in the Niño $1+2$ region, which is the far eastern equatorial Pacific $\left(0-10^{\circ} \mathrm{S}, 90^{\circ} \mathrm{W}-80^{\circ} \mathrm{W}\right)$, adjacent to the Peruvian coast. Other agencies use the Niño3.4 index (central equatorial Pacific Ocean) and consider the SST changes, the expected duration of these increases and the engagement with the atmosphere ${ }^{4}$. This definition also requires that there be a number of months where the SST has exceeded a set limit.

The reason for different criteria to define an El Niño event is the varying effects on each country. Peru uses the Niño1+2 index, as this detects when the warm, low-nutrient waters replace the cool, nutrient-rich waters that normally upwell in the region and sustain primary productivity. In June 2014, waters $3{ }^{\circ} \mathrm{C}$ warmer than average were observed in the region ${ }^{5}$. Peruvian fishermen are directly affected as anchovy stocks (a key fishery for the country) are reduced under these conditions ${ }^{6}$. The term El Niño (the little boy or 'Child Jesus') was actually coined by fishermen of the region as warmer waters and reduced stocks have historically been observed after Christmas? ${ }^{7}$.

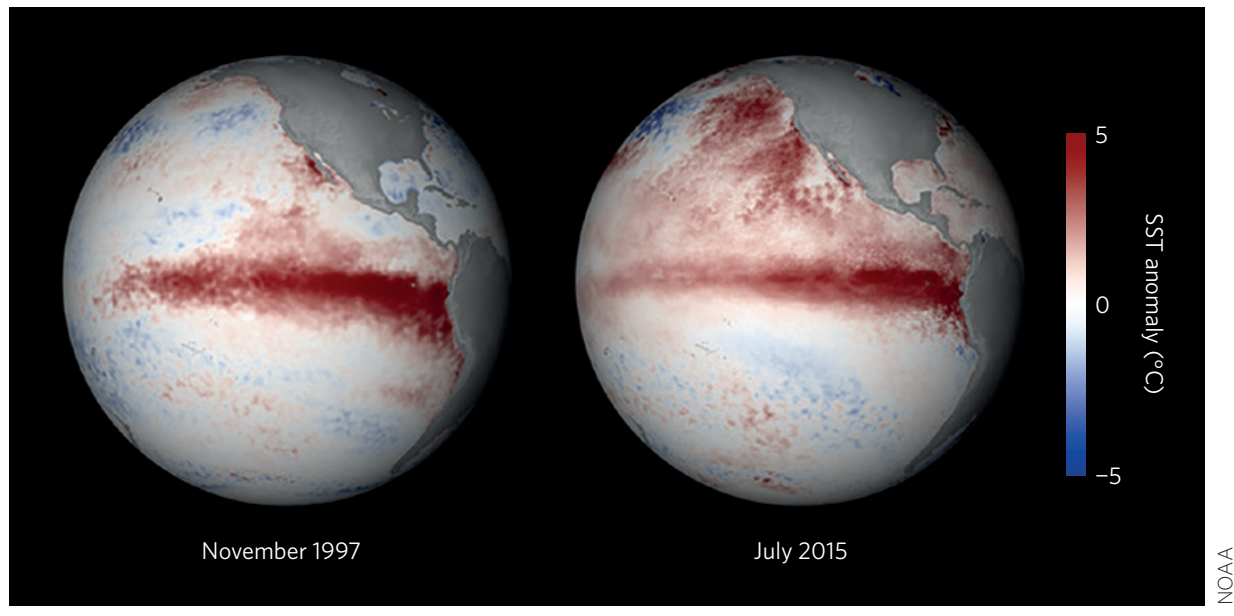

The El Niño phenomenon has been known for many years, but how much do we understand this natural variability of the climate system? In a web focus this month, ENSO Under Change (http:// www.nature.com/nclimate/focus/ensounder-change/index.html), we present a collection of pieces alongside a selection from the archives of Nature Climate Change, Nature, Nature Geoscience and Nature Communications. This body of work investigates how climate change is impacting on ENSO, and more specifically how it is affecting the severity and frequency of extreme ENSO events ${ }^{8}$.

Although many people are familiar (particularly those who reside in countries affected) with the hydrological changes associated with the ENSO phenomenon, there are other, less-known effects. One of these is increases in cyclone intensity in the western Pacific ${ }^{9}$. The increase is thought to result from a shift in the location where the storms form - warm central Pacific waters. The shift away from land means the storms have more time in open water to gain strength before making landfall. Climate change is thought to play a role in storm frequency, with increased intensity storms expected. This could result in devastation of the communities in their path, although overall storm occurrence may decrease ${ }^{10}$. A sobering thought, as (at the time of writing) another storm, Typhoon Soudelor, is ramping up in the Western Pacific Ocean.
Scientists are working towards understanding the dynamics at play in the Pacific Ocean, but as the climate changes we don't have a stable baseline for comparisons. So let's just consider what is happening now - current information (such as the SST anomalies shown above, which tell only a small part of the story) is that a strong event is underway. The impacts on communities is difficult to predict and only time will tell how extreme the event will become. If anything, the last year and the false start have just reminded us that we still have a lot to learn about this planet of ours.

\footnotetext{
References

1. ENSO: Recent Evolution, Current Status and Predictions (NOAA Climate Prediction Centre, 2015); http://go.nature.com/BCTp44

2. McPhaden, M. J. Nature Clim. Change 5, 791-795 (2015).

3. Miller, C. El Niño update: California’s 'Great Wet Hope' continues to build. KQED Science (9 July 2015); http://go.nature.com/fRuApd

4. Becker, E. December's ENSO update: close, but no cigar. Climate.gov (4 December 2014); http://go.nature.com/ZqMhNG

5. Villegas, A. Extraordinary El Nino off Peruvian coast not expected by year-end, says research body. Undercurrent News (26 June 2014); http://go.nature.com/2DFevQ

6. Ñiquen, M. \& Bouchon, M. Deep Sea Res. Pt II 51, 563-564 (2004).

7. Philander, S. G. H. El Nino, La Nina, and the Southern Oscillation (Academic Press, 1989).

8. Cai, W. et al. Nature Clim. Change 5, 849-859 (2015).

9. Camargo, S. J. \& Sobel. A. H. J. Clim. 18, 2996-2006 (2005).

10. Kang, N.-Y. \& Elsner, J. B. Nature Clim. Change 5, 661-664 (2015).
}

Published online: 17 August 2015 